\title{
ANALISIS PENGARUH BUDAYA ORGANISASI DAN ETOS KERJA TERHADAP KINERJA PEGAWAI (STUDI KASUS DINAS KELAUTAN DAN PERIKANAN DAERAH ISTIMEWA YOGYAKARTA)
}

\author{
Nofika Amalia \\ Puji Astuti \\ Universitas Teknologi Yogyakarta \\ pujiastuti_uty@yahoo.com
}

\begin{abstract}
This study aims to determine the effect of organizational culture and work ethic on employee performance in the Department of Maritime Affairs and Fisheries of the Special Region of Yogyakarta. This research was conducted in March to April 2019. The sample used in this study were all employees, amounting to 57 people. The sampling technique uses the saturated sample method or takes the entire total population. Data collection methods used were qualitative using a questionnaire. Data analysis techniques in this study used the analysis of the research instrument test, classic assumption test, multiple linear regression test, partial test ( $t$ test), simultaneous test ( $f$ test), and coefficient of determination test. Multiple linear analysis is used to test the hypothesis of this study. The results showed that: (1) Organizational culture ( $\left.X_{P}\right)$ has a positive effect on employee performance $(Y)$, as evidenced by the $t_{\text {count }}$ value of organizational culture of $2.986>t_{\text {table }} 2.004$. (2) Work ethic $\left(X_{2}\right)$ has a positive effect on employee performance $(Y)$, as evidenced by the value of $t$-work ethic of $0.386>t_{\text {table }} 2.004$. (3) Organizational culture and work ethics simultaneously have a significant effect on employee performance as evidenced by the f-count value of $22.723>f_{\text {table }} 3.16$. The adjusted $R$ square variant value $=0.437$ or $43.7 \%$, meaning that the organizational culture and work ethic variables are able to explain the employee performance variable of $43.7 \%$, while the remaining $56.3 \%$ is explained by other variables not examined in this study.
\end{abstract}

Keywords: Organizational Culture; Work Ethics; Employee Performance

\section{PENDAHULUAN}

Sumber Daya Manusia (SDM) merupakan aspek penting dalam suatu organisasi yang berperan aktif menjadi penentu keberhasilan suatu organisasi. Keterlibatan SDM sebagai penggerak dalam perusahaan terimplementasi dalam bentuk tenaga kerja, pegawai, atau karyawan. Karyawan sebagai SDM dalam suatu organisasi merupakan faktor penting bagi peningkatan produktifitas dan kemajuan perusahaan tersebut. Tanpa adanya SDM perusahaan tersebut tidak akan dapat maju dan berkembang. Keberlangsungan suatu organisasi tentu saja bergantung pada baik atau buruknya kinerja dari sebuah organisasi tersebut.

Peran penting SDM dalam organisasi adalah semua potensi yang dimiliki manusia dapat dimanfaatkan sebagai usaha untuk meraih keberhasilan dalam mencapai tujuan baik secara individu maupun di dalam organisasi. Mangkunegara (2017) menyatakan bahwa manajemen sumber daya manusia merupakan perencanaan, pengorganisasian, pengkoordinasian, pelaksanaan, dan pengawasan terhadap pengadaan, 
Pengaruh Budaya Organisasi dan Etos Kerja terhadap Kinerja Pegawai (Studi Kasus Dinas Kelautan dan Perikanan

pengembangan, pemberian balas jasa, pengintegrasian, pemeliharaan, dan pemisahan tenaga kerja dalam rangka mencapai tujuan organisasi.

Etos kerja merupakan sifat, watak dan kualitas kehidupan manusia, moral dan gaya estetik serta suasana batin mereka. Etos kerja merupakan sikap mendasar terhadap diri dan dunia mereka yang direfleksikan dalam kehidupan nyata, semua orang perlu perlu memiliki etos kerja yang tinggi. Sinamon (2011) menyatakan bahwa etos kerja adalah seperangkat perilaku positif yang berakar pada keyakinan fundamental yang disertai komitmen total pada paradigma kerja yang integral. Istilah paradigma berarti konsep utama tentang kerja itu sendiri yang mencangkup idealisme yang mendasari prinsip-prinsip yang mengatur, nilai-nilai yang menggerakkan, sikap-sikap yang dilahirkan, standar-standar yang hendak dicapai, termasuk karakter utama, pikiran dasar, kode etik, kode moral, dan kode perilaku bagi para penganutnya.

Pegawai yang memiliki etos kerja tinggi akan mempunyai semangat untuk memberikan pengaruh positif kepada lingkungannya. Keberadaan dirinya diukur oleh sejauh mana potensi yang dimilikinya memberikan makna dan pengaruh yang mendalam pada orang lain. Etos kerja yang tinggi sangat diperlukan dalam kehidupan berorganisasi untuk mempercepat tercapainya tujuan organisasi. Dengan demikian, maka dapat dikatakan bahwa etos kerja memiliki pengaruh terhadap kinerja pegawai.

Budaya organisasi merupakan pola keyakinan dan nilai-nilai yang dipahami dan jiwai oleh anggota organisasi, sehingga pola tersebut memberikan makna tersendiri bagi organisasi yang bersangkutan dan menjadi dasar aturan berperilaku di dalam organisasi.

Nawawi (2013) menyatakan bahwa budaya organisasi adalah nilai-nilai yang menjadi pegangan SDM dalam menjalankan kewajiban dan perilakunya di dalam organisasi. Mangkunegara (2013) mengatakan bahwa budaya organisasi adalah seperangkat asumsi atau sistem keyakinan, nilai-nilai dan norma yang dikembangkan dalam organisasi. Nilainilai dan norma-norma dalam organisasi akan dianut dan dijalankan oleh setiap anggota. Nilai-nilai dan norma dalam suatu organisasi akan mempengaruhi tingkah laku anggotanya maupun dalam melaksanakan setiap tugas yang diberikan. Baik atau buruk kinerja anggota akan mempengaruhi tercapai atau tidaknya tujuan suatu organisasi.

Budaya organisasi di lingkungan pemerintahan sangatlah berbeda dengan lingkungan bisnis maupun swasta. Jika pada lingkungan pemerintahan regulasi yang ditetapkan oleh pemerintah namun pada swasta selalu berbeda antara satu dengan yang lainnya. Budaya organisasi pemerintahan seharusnya dapat mengakomodasi pembangunan dan hubungan internal, sehingga nilai tersebut dapat dimiliki setiap orang dalam suatu organisasi dalam hal ini dinas di lingkungan pemerintahan.

Nawawi (2013) menyatakan bahwa kinerja merupakan hasil yang dicapai oleh pegawai atas aktivitas kerja yang dilakukan oleh organisasi. Mangkunegara (2013) mengatakan bahwa istilah kinerja berasal dari katajob performance atau actual performance yaitu prestasi kerja atau kinerja sesungguhnya dari seorang pegawai atau karyawan, maka pengertian kinerja adalah hasil kerja secara kualitas dan kuantitas yang dicapai oleh seorang pegawai dalam melaksanakan tugasnya sesuai dengan tanggung jawab yang diberikan kepadanya.

Kinerja dikatakan tinggi apabila suatu target kerja dapat diselesaikan dengan tepat waktu atau tidak melampaui batas waktu yang disediakan. Kinerja menjadi rendah jika diselesaikan melampaui batas waktu yang telah ditentukan atau sama sekali tidak selesai. Dengan demikian kinerja dapat dikatakan sangat tinggi jika target kerja dapat diselesaikan lebih cepat dari waktu yang disediakan.

Dinas Kelautan dan Perikanan Daerah Istimewa Yogyakarta(DIY) merupakan instansi pemerintah yang bekerja untuk melaksanakan urusan pemerintahan daerah di bidang kelautan dan perikanan, kewenangan dekonsentrasi serta tugas pembantu yang diberikan oleh 
pemerintah. Oleh karena itu, Pegawai Negeri Sipil (PNS) dan Tenaga Bantu (Naban) dituntut untuk mengikuti semua peraturan yang telah ditetapkan untuk bekerja secara profesional. Tenaga kerja yang terdapat di Dinas Kelautan dan Perikanan DIY sebanyak 58 orang PNS dan 19 orang non PNS atau tenaga bantu, maka dapat diketahui jumlah tenaga kerja sebanyak 77 pegawai. Tentunya semua pegawai harus bekerja dan menyelesaikan tugas sesuai dengan yang diharapkan.

Pada umumnya setiap instansi atau organisasi mempunyai etos kerja dan budaya organisasi yang berbeda-beda. Setiap individu memiliki karakter dan latar belakang yang berbeda satu sama lain. Rendahnya etos kerja yang dimiliki oleh setiap pegawai mengakibatkan rendahnya kinerja pegawai itu sendiri. Masih ada beberapa pegawai yang tidak memanfaatkan jam kerja yang ada tetapi mengurangi jam kerja mereka seperti pulang lebih awal atau berpergian yang tidak ada kaitannya dengan urusan kerja.

Rendahnya tingkat kedisiplinan mengakibatkan pegawai sering datang terlambat dan ketika jam kerja tidak berada di tempat kerjanya. Hal tersebut tentu akan menghambat pekerjaan. Masih ada beberapa pegawai yang kurang memiliki sikap tanggung jawab atas pekerjaannya dapat dilihat dimana pegawai mengerjakan pekerjaannya kurang bersungguh-sungguh, hasilnya pekerjaan tersebut akan mundur dari waktu yang telah ditentukan.

Selanjutnya, tingkat kejujuran pegawai dirasa masih rendah. Beberapa pegawai masih ada yang mencuri-curi waktu kerja untuk duduk dan mengobrol dengan pegawai lain, sehingga pegawai melupakan kewajibannya untuk bekerja. Selain itu, masih rendahnya semangat kerja mengakibatkan pegawai cenderung malas untuk mengerjakan pekerjaannya lebih cepat. Masih ada beberapa pegawai yang mengerjakan pekerjaannya mendekati waktu yang telah ditentukan, sehingga pegawai akan mengerjakan pekerjaan dengan terburu-buru dan hasilnya kurang maksimal.
Berikut merupakan salah satu tabel indikator etos kerja, tabel ketidakhadiran pegawai pada Dinas Kelautan dan Perikanan DIY selama periode bulan Januari - Maret 2019 sebagai berikut:

\section{Tabel 1.1}

Rekapitulasi Kehadiran dan Ketidakhadiran Pegawai Dinas Kelautan dan Perikanan DIY Bulan Januari-Maret 2019

\begin{tabular}{|l|c|c|c|c|}
\hline \multirow{4}{*}{ Bulan } & \multicolumn{3}{|c|}{ Kehadiran } & Ketidakhadiran \\
\cline { 2 - 5 } & $\begin{array}{c}\text { Terlambat } \\
\text { Datang dan } \\
\text { Pulang } \\
\text { Mendahului } \\
\text { (Orang) }\end{array}$ & $\begin{array}{c}\text { Tidak Absen } \\
\text { Datang } \\
\text { (0rang) }\end{array}$ & $\begin{array}{c}\text { Tidak Absen } \\
\text { Pulang } \\
\text { (Orang) }\end{array}$ & $\begin{array}{c}\text { Tanpa } \\
\text { Keterangan } \\
\text { (Orang) }\end{array}$ \\
\hline Januari & 32 & 13 & 14 & 2 \\
\hline Februari & 42 & 7 & 12 & \\
\hline Maret & 37 & 6 & 16 & \\
\hline
\end{tabular}

Sumber : Dinas Kelautan dan Perikanan DIY

Masalah keterlambatan kerja merupakan salah satu faktor indikator etos kerja yaitu faktor disiplin. Dari data pada tabel 1.1 di atas terlihat bahwa dari periode Januari - Maret menunjukkan masih banyak pegawai yang tidak mentaati tata tertib yang telah ditetapkan Dinas Kelautan dan Perikanan DIY. Hal ini terlihat dengan banyaknya pegawai yang datang terlambat, tidak absen pada saat datang, dan tidak absen pada saat pulang. Begitu juga dengan ketidakhadiran pegawai yang tidak masuk kantor tanpa keterangan yang mengakibatkan pekerjaan pegawai tidak selesai tepat waktu, sehingga target tidak tercapai. Jika target itu tidak tercapai berarti kinerja pegawai masih rendah. Kurangnya kesadaran diri dari setiap pegawai untuk mengefisiensi waktu sebaik mungkin dan kurang taatnya dengan peraturan-peraturan yang telah ada di instansi membuat kinerja para pegawai kurang baik atau rendah. Hal ini merupakan masalah yang harus diselesaikan dan diperbaiki oleh organisasi pada Dinas Kelautan dan Perikanan DIY.

Budaya organisasi yang kuat akan menumbuhkan rasa tanggung jawab yang besar dari pegawai, sehingga mampu memotivasi untuk menampilkan kinerja yang paling 
Pengaruh Budaya Organisasi dan Etos Kerja terhadap Kinerja Pegawai (Studi Kasus Dinas Kelautan dan Perikanan

maksimal dan dapat mencapai tujuan yang lebih baik. Pada kenyataannya di kantor Dinas Kelautan dan Perikanan DIY masih ditemukan beberapa pegawai yang kurang mentaati tata tertib organisasinya dalam bekerja, misalnya izin untuk keperluan pribadi, pada saat hari Kamis Pahing yang seharusnya memakai pakaian tradisional tapi masih banyak pegawai yang tidak memakai sesuai anjuran dari pimpinan, beristirahat melebihi waktu yang telah di tentukan oleh kantor, dan setiap hari Jumat seharusnya pegawai melakukan kegiatan berolahraga, namun masih ada beberapa pegawai yang tidak melakukan budaya berolahraga setiap hari Jumat.

Tabel 1.2

Kinerja Pegawai Dinas Kelautan dan Perikanan DIY Bulan Januari-Maret 2019

\begin{tabular}{|c|l|c|c|}
\hline Bulan & \multicolumn{1}{|c|}{ Kegiatan } & Target & Realisasi \\
\hline Januari & $\begin{array}{l}\text { Pelatihan peningkatan } \\
\text { produksi perikanan tangkap }\end{array}$ & 11 Januari & 16 Januari \\
\hline Februari & $\begin{array}{l}\text { Pelayanan pengendalian } \\
\text { penyakit ikan }\end{array}$ & 5 Februari & 14 Februari \\
\hline Maret & $\begin{array}{l}\text { Pelatihan perbanyakan induk, } \\
\text { benih unggul, dan teknologi } \\
\text { perikanan budidaya }\end{array}$ & 20 Maret & 24 Maret \\
\hline
\end{tabular}

Sumber : Dinas Kelautan dan Perikanan DIY

Dari data di atas dapat dilihat bahwa pada bulan Januari - Maret masih terdapat kegiatan yang tidak sesuai dengan target yang telah ditentukan. Dengan demikian kinerja pegawai masih rendah dan kurangnya kesadaran pegawai terhadap pekerjaan yang telah ditarget oleh pimpinan.

\section{REVIEW LITERATUR DAN HIPOTESIS}

\section{Landasan Teori}

\section{A. Manajemen Sumber Daya Manusia}

Manajemen Sumber Daya Manusia (MSDM) merupakan salah satu cabang ilmu manajemen yang timbul setelah disadari bahwa manusia mempunyai kedudukan yang utama dalam organisasi, dimana bidang ini berusaha mengkoordinasikan para karyawannya dengan segala persoalannya agar dapat menjalankan tugasnya dengan sebaik mungkin dan memberikan sumbangan yang optimal bagi perusahaan. Hasibuan (2013) mengatakan bahwa MSDM adalah ilmu seni mengatur hubungan dan peranan tenaga kerja agar efektif dan efisien membantu terwujudnya tujuan perusahaan, karyawan, dan masyarakat. Mangkunegara (2017) mengatakan bahwa MSDM merupakan suatu perencanaan, pengorganisasian, pengkoordinasian, pelaksanaan, dan pengawasan terhadap pengadaan pengembangan, pemberian balas jasa, pengintegrasian, pemeliharaan, dan pemisahan tenaga kerja dalam rangka mencapai tujuan organisasi.

Berdasarkan uraian-uraian mengenai pengertian MSDM di atas dapat disimpulkan bahwa manajemen sumber daya manusia merupakan suatu perencanaan, pengorganisasian, pengkoordinasian dimana terhadap proses penarikan, seleksi, pengembangan, pemeliharaan, dan penggunaan sumber daya manusia untuk mencapai tujuan individu maupun organisasi.

\section{B. Budaya Organisasi}

Ardana (2012) mengatakan bahwa budaya organisasi yang kuat dan telah berakar akan dapat memberikan kontribusi yang cukup signifikan bagi anggota organisasi dalam hal pemahaman yang jelas dan lugas tentang suatu persoalan diselesaikan. Budaya memiliki pengaruh berarti pada sikap perilaku anggotaanggota organisasi. Wibowo (2013) mengatakan bahwa budaya organisasi adalah filosofi dasar organisasi yang memuat keyakinan, norma-norma, dan nilai-nilai bersama yang menjadi karakteristik inti tentang bagaimana cara melakukan sesuatu dalam organisasi.

Schein (dalam Raini, 2011) mengatakan bahwa budaya organisasi adalah sebagai suatu pola dari asumsiasumsi dasar yang ditemukan, diciptakan, 
atau dikembangkan oleh suatu kelompok tertentu dengan tujuan agar organisasi belajar mengatasi atau menanggulangi masalah yang timbul akibat adaptasi eksternal dan integrasi internal yang sudah berjalan cukup baik, sehingga perlu diajarkan kepada anggota-anggota baru sebagai cara yang benar untuk memahami, memikirkan, dan merasakan berkenaan dengan masalah-masalah tersebut. Budaya organisasi dibentuk sendiri oleh suatu kelompok organisasi untuk bergerak dalam mengatasi tantangan-tantangan masa depan.

Budaya organisasi sangat penting bagi pegawai. Adanya budaya yang kuat dapat membuat pegawai merasa menjadi bagian dari organisasi mereka akan melakukan apapun demi tercapainya tujuan organisasi untuk itu budaya yang baik dan kuat sangat penting dalam mempengaruhi pegawai untuk meningkatkan kinerja para pegawai. Jadi, budaya organisasi adalah sebuah identitas dari sebuah organisasi untuk membedakan dengan organisasi lain. Budaya organisasi tersebut di bentuk dan diterapkan oleh anggota organisasi itu sendiri. Budaya organisasi juga dapat menentukan keberhasilan sebuah organisasi dalam menjalankan visi dan misinya.

\section{Etos Kerja}

Istilah etos berasal dari bahasa Yunani (ethos) yang memberikan arti sikap, kepribadian, watak, karakter, serta keyakinan atas sesuatu. Sikap ini tidak saja dimiliki oleh individu, tetapi juga oleh kelompok bahkan masyarakat. Etos dibentuk oleh berbagai kebiasaan, pengaruh budaya, serta sistem nilai yang diyakininya. Dari kata etos, dikenal pula kata etika, etiket yang hampir mendekati pada pengertian akhlak atau nilai-nilai yang berkaitan dengan baik buruk (moral), sehingga dalam etos tersebut terkandung gairah atau semangat yang amat kuat untuk menyempurnakan sesuatu secara optimal, lebih baik, dan bahkan berupaya untuk mencapai kualitas kerja yang sesempurna mungkin.

Etos adalah sifat, karakter, kualitas hidup, moral, dan gaya estetika serta suasana hati seseorang. Kemudian etos berada pada lingkaran etika dan logika yang bertumpuk pada nilai-nilai dalam hubungannya pola-pola tingkah laku dan rencana-rencana manusia. Sinamon (2011) mengatakan bahwa etos kerja adalah seperangkat perilaku positif yang berakar pada keyakinan fundamental yang disertai komitmen total pada paradigma kerja yang integral.

\section{Kinerja}

Mangkunegara (2013) mengatakan bahwa kinerja dapat didefinisikan sebagai hasil kerja secara kualitas dan kuantitas yang dapat dicapai oleh seorang karyawan dalam melaksanakan tugas sesuai dengan tanggung jawabyang diberikan kepadanya. Moeheriono (2012) menyatakan bahwa kinerja atau performance merupakan gambaran mengenai tingkat pencapaian pelaksanaan dari suatu program kegiatan atau kebijakan dalam mewujudkan sasaran, tujuan, visi, dan misi organisasi yang dituangkan melalui perencanaan strategis suatu organisasi. Kinerja dapat diketahui dan diukur jika individu atau kelompok karyawan telah memiliki kriteria atau standar keberhasilan tolak ukur yang telah ditetapkan organisasi.

\section{Hipotesis}

\section{Pengaruh Positif Etos Kerja terhadap Kinerja Karyawan}

Sinamon (dalam Intan, 2017) menyatakan bahwa etos kerja adalah seperangkat perilaku positif yang berakar pada keyakinan fundamental yang disertai komitmen total pada paradigma kerja yang integral. Pegawai yang memiliki etos kerja yang tinggi berarti memiliki semangat kerja yang tinggi untuk melakukan suatu tugas agar lebih optimal. Etos kerja 
berpengaruh pada kinerja pegawai karena semakin baik etos kerja yang dimiliki para pegawai, maka semakin baik pula kinerja pegawai. Penelitian sebelumnya yang dilakukan oleh Karauwan (2015) dan Pramana (2017) menunjukkan bahwa etor kerja berpengaruh positif terhadap kinerja karyawan. Dari penjelasan di atas, maka dapat ditarik hipotesis:

\section{H1 :Terdapat Pengaruh Positif Etos Kerja terhadap Kinerja Karyawan.}

2. Pengaruh Positif Budaya Organisasi terhadap Kinerja Karyawan

Budaya organisasi berpengaruh terhadap kinerja karyawan. Menurut Robbins (dalam Wibowo, 2013) menyatakan bahwabudaya organisasi yang disosialisasikan dengan komunikasi yang baik akan dapat menemukan kekuatan menyeluruh organisasi, kinerja, dan daya saing dalam jangka panjang. Budaya organisasi yang dijunjung tinggi akan menjadi pedoman bagi karyawan dalam menentukan sikap mengenai apa yang dipertahankan di organisasi itu. Sikap yang mendukung dan tidak mendukung ini kemudian mempengaruhi kinerja individu karyawan. Penelitian sebelumnya yang dilakukan oleh Karauwan (2015) menunjukkan etos kerja berpengaruh positif terhadap kinerja karyawan. Dari penjelasan di atas, maka dapat ditarik hipotesis:

\section{H2 :Terdapat Pengaruh Positif Budaya Organisasi terhadap Kinerja Karyawan.}

3. Pengaruh Simultan Etos Kerja dan Budaya Organisasi terhadap Kinerja Karyawan

Etos kerja dan budaya organisasi diindikasikan memiliki pengaruh yang secara bersama-sama (simultan) terhadap kinerja pegawai Dinas Kelautan dan Perikanan DIY. Tingginya etos kerja pada pegawai akan membentuk karakter pegawai yang lebih baik dalam bekerja dan menjalankan tugasnya. Selain itu, organisasi dengan budaya yang kuat akan mempengaruhi perilaku dan efektivitas kinerja pegawai. Hal ini mengindikasikan bahwa etos kerja dan budaya organisasi, kedua variabel tersebut berdampak atau menimbulkan pengaruh terhadap kinerja pegawai Dinas Kelautan dan Perikanan DIY. Etos kerja yang tinggi dan budaya organisasi yang kuat dalam bekerja akan meningkatkan kinerja pegawai dan membawa organisasi untuk dapat mencapai tujuannya.

H3 :Etos Kerja dan Budaya Organisasi secara Simultan Berpengaruh Signifikan terhadap Kinerja Karyawan

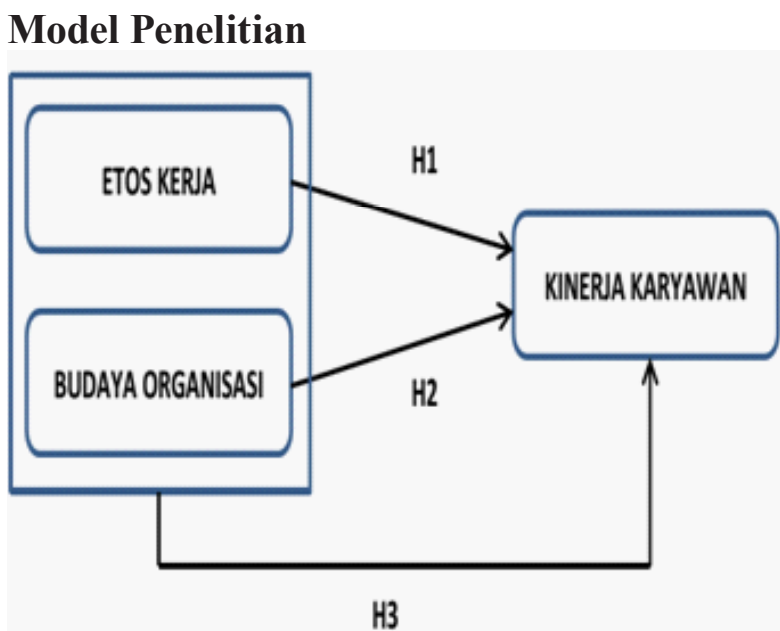

Gambar 1. Model Penelitian

\section{METODE PENELITIAN}

\section{Populasi dan Sampel}

Penelitian dilakukan di Dinas Kelautan dan Perikanan DIY yang berlokasi di Jalan Sagan III/4, Terban, Kecamatan Gondokusuman, Kota Yogyakarta, Daerah Istimewa Yogyakarta. Sugiyono (2015) menyatakan bahwa populasi adalah wilayah generalisasi yang terdiri atas obyek atau subyek yang mempunyai kuantitas dan karakteristik tertentu yang ditetapkan oleh peneliti untuk dipelajari dan kemudian ditarik 
kesimpulannya. Populasi penelitian ini adalah seluruh pegawai Dinas Kelautan dan Perikanan DIY yang berjumlah 58 orang.

Teknik pengambilan sampel dalam penelitian ini menggunakan teknik nonprobability yaitu sampel jenuh atau sering disebut total sampling. Sugiyono (2013) menyatakan bahwa sampel jenuh, yaitu teknik penentuan sampel dengan cara mengambil seluruh anggota populasi sebagai responden atau sampel. Jadi sampel dalam penelitian ini adalah seluruh pegawai Dinas Kelautan dan Perikanan berjumlah 58 orang.

Menurut Arikunto (2010) penentuan pengambilan sampel apabila populasi kurang dari 100 lebih baik diambil semua, sehingga penelitiannya merupakan penelitian populasi. Jika jumlah subyeknya lebih besar dapat diambil antara $10-15 \%$ atau $30-50 \%$ dari total populasi. Dalam penelitian ini jumlah sampel adalah 58 orang sama dengan populasi, atau seluruh karyawan Dinas Kelautan dan Perikanan DIY.

\section{Variabel Penelitian}

\section{Variabel Dependen}

Sugiyono (2013) menyatakan bahwa variabel dependen atau variabel terkait merupakan variabel yang dipengaruhi atau yang menjadi akibat karena adanya variabel bebas (variabel independen). Dalam penelitian ini yang menjadi variabel terkait dependen adalah Kinerja Pegawai (Y).

\section{Variabel Independen}

Sugiyono (2015) menyatakan bahwa varibel independen atau variabel bebas merupakan variabel yang mempengaruhi atau yang menjadi sebab perubahannya atau timbulnya variabel dependen (terkait). Variabel independen dalam penelitian ini terdiri dari dua variabel yaitu etos kerja $\left(\mathrm{X}_{1}\right)$ dan budaya organisasi $\left(\mathrm{X}_{2}\right)$.

\section{Teknik Analisis Data \\ Uji Instrumen}

\section{Uji Validitas}

Uji validitas digunakan untuk mengukur sah atau valid dan tidaknya kuesioner. Kuesioner dikatakan valid jika pertanyaan atau pernyataan pada kuesioner mampu mengungkapkan sesuatu yang diukur oleh kuesioner tersebut (Ghozali, 2018). Suatu pertanyaan yang dikatakan valid jika terjadi korelasi yang signifikan antara masing-masing pertanyaan atau pernyataan dengan jumlah skor yang ditunjukkan dengan $r_{\text {hitung }}>r_{\text {tabel }}$ dan sebaliknya jika $r_{\text {hitung }}<r_{\text {tabel }}$, maka kuesioner dinyatakan tidak valid.

\section{Uji Reliabilitas}

Uji validitas digunakan untuk mengukur sah atau valid dan tidaknya kuesioner. Kuesioner dikatakan valid jika pertanyaan atau pernyataan pada kuesioner mampu mengungkapkan sesuatu yang diukur oleh kuesioner tersebut (Ghozali, 2018). Suatu pertanyaan yang dikatakan valid jika terjadi korelasi yang signifikan antara masing-masing pertanyaan atau pernyataan dengan jumlah skor yang ditunjukkan dengan $r_{\text {hitung }}>r_{\text {tabel }}$ dan sebaliknya jika $r_{\text {hitung }}<r_{\text {tabel }}$, maka kuesioner dinyatakan tidak valid.

\section{Uji Asumsi Klasik}

\section{Uji Normalitas}

Uji normalitas bertujuan untuk menguji apakah dalam model regresi variabel dependen dan independennya memiliki distribusi normal atau tidak. Adapun uji normalitas dengan statistik yang digunakan dalam penelitian ini adalah uji Kolmogorov-Smirnov (KS test), yaitu dengan melihat angka probabilitas signifikansi lebih besar dari 0,05. Jika data menyebar di sekitar garis diagonal dan mengikuti arah garis diagonal maka model regresi memenuhi asumsi normalitas (Ghozali, 2018). 
Pengaruh Budaya Organisasi dan Etos Kerja terhadap Kinerja Pegawai (Studi Kasus Dinas Kelautan dan Perikanan

Daerah Istimewa Yogyakarta)

\section{Uji Heteroskedastisitas}

Uji heteroskedastisitas bertujuan untuk menguji apakah dalam model regresi terjadi ketidaksamaan varian dari residual satu pengamatan ke pengamatan yang lain. Jika varian dari residual satu pengamatan ke pengamatan lain tetap, maka disebut homokedastisitas dan jika berbeda disebut heteroskedastisitas. Model regresi yang baik adalah yang homokedastisitas atau tidak terjadi heteroskedastisitas (Ghozali, 2018).

Salah satu cara melihat adanya heteroskedastisitas adalah dengan melihat grafik scatterplot antara nilai prediksi variabel terkait (ZPRED) dengan residualnya (SRESID). Menurut Ghozali (2018) dasar pengambilan keputusan uji tersebut yaitu sebagai berikut:

1) Jika ada titik-titik yang membentuk pola tertentu yang teratur seperti bergelombang melebar kemudian menyempit, maka mengindikasikan adanya heteroskedastisitas.

2) Jika tidak terdapat pola tertentu yang jelas, serta titik-titik menyebar di atas dan di bawah angka 0 pada sumbu Y, maka mengindikasikan tidak terjadi heteroskedastisitas.

\section{Uji Multikolinieritas}

Uji multikolinieritas bertujuan untuk menguji apakah dalam model regresi ditemukan adanya korelasi antara variabel bebas (independen). Model regresi yang baik seharusnya tidak terjadi korelasi diantara variabel bebas (independen). Untuk mendeteksi ada atau tidaknya multikolinieritas di dalam model regresi, yakni dengan melihat dari nilai tolerance, dan lawannya, yaitu variance inflation factor (VIF). Nilai tolerance $<0,10$, atau sama dengan nilai VIF $>10$. Apabila di dalam model regresi tidak ditemukan asumsi deteksi seperti di atas, maka model regresi yang digunakan dalam penelitian ini bebas dari multikolinieritas, dan demikian pula sebaliknya (Ghozali, 2018).

\section{Analisis Regresi Linier Berganda}

Analisis regresi linier berganda yaitu suatu metode statistik yang digunakan untuk mengetahui pengaruh antara dua atau lebih variabel independen dengan satu variabel dependen, yang mana variabel bebas tersebut terdiri dari etos kerja dan budaya organisasi sedangkan yang menjadi variabel terkait yaitu kinerja pegawai. Pengaruh antara variabel bebas dengan variabel terikat ditunjukkan dengan fungsi persamaan regresi linier berganda (Sugiyono, 2014). Untuk mengetahui pengaruh variabel bebas terhadap variabel terkaitnya dengan bantuan SPSS digunakan rumus analisis regresi berganda sebagai berikut:

$\mathbf{Y}=\mathbf{a}+\boldsymbol{\beta}_{1} \mathbf{X}_{1}+\boldsymbol{\beta}_{2} \mathbf{X}_{2}$

Keterangan:

$\mathrm{Y}=$ Kinerja Karyawan

$\mathrm{a}=$ Konstanta

$\beta_{1}=$ Koefisien Regresi Variabel $\mathrm{X}_{1}$

$\beta_{2}=$ Koefisien Regresi Variabel $X_{2}$

$\mathrm{X}_{1}=$ Etos Kerja

$\mathrm{X}_{2}=$ Budaya Organisasi

\section{Uji Hipotesis}

\section{Uji Parsial (Uji T)}

Uji parsial atau uji $t$ adalah pengujian yang dilakukan untuk menunjukkan pengaruh satu variabel independen secara individual dalam menerangkan variasi variabel dependen (Ghozali, 2018). Uji t dilakukan dengan melihat nilai signifikansi t masing-masing variabel pada output hasil regresi dengan taraf signifikansi $0,05(\alpha=5 \%)$.

Jika $\mathrm{P}$ value $<0,05$, maka variabel independen berpengaruh secara signifikan terhadap variabel dependen. Sebaliknya, jika $\mathrm{P}$ value $>0,05$, maka variabel independen tidak berpengaruh secara signifikan terhadap variabel dependen.

\section{Uji Simultan (Uji F)}

Penelitian ini menggunakan uji $\mathrm{F}$ untuk mengetahui tingkat signifikansi pengaruh variabel-variabel independen secara simultan terhadap variabel dependen (Ghozali, 2018). Apabila nilai signifikansi menunjukkan $<0,05$, maka dapat dikatakan variabel independen 
secara simultan berpengaruh signifikan terhadap variabel dependen. Sebaliknya, jika nilai signifikansi $>0,05$, maka variabel independen secara simultan tidak berpengaruh signifikan terhadap variabel dependen. Dalam penelitian ini pengujian hipotesis secara simultan dimaksudkan untuk mengukur besarnya pengaruh etos kerja $\left(\mathrm{X}_{1}\right)$ dan budaya organisasi $\left(\mathrm{X}_{2}\right)$ terhadap kinerja pegawai $(\mathrm{Y})$ secara bersama-sama.

\section{Uji Koefisien Determinasi}

Uji koefisien determinasi bertujuan untuk mengukur sejauh mana variabel bebas dapat menjelaskan variasi variabel terikat baik secara parsial maupun simultan. Nilai koefisien determinasi ini adalah antara nol sampai dengan satu $\left(0<\mathrm{R}^{2}<1\right)$. Ghozali (2012) mengatakan nilai $\mathrm{R}^{2}$ yang kecil mengandung arti bahwa kemampuan variabel bebas dalam menjelaskan variasi variabel terkait sangat terbatas. Sebaliknya, nilai $\mathrm{R}^{2}$ yang hampir semua informasi yang dibutuhkan untuk memprediksi variasi variabel independen.

\section{HASIL PENELITIAN DAN PEMBAHASAN}

\section{Analisis Responden}

1. Berdasarkan Jenis Kelamin

Tabel 4.1

Karakteristik Responden

Berdasarkan Jenis Kelamin

\begin{tabular}{|c|c|c|}
\hline Jenis Kelamin & Jumlah Responden & Persentase (\%) \\
\hline Laki-laki & 33 & $58 \%$ \\
\hline Perempuan & 24 & $42 \%$ \\
\hline Total & 57 & $100 \%$ \\
\hline
\end{tabular}

Dari tabel 4.1 di atas menunjukkan bahwa responden yang terlibat dalam penelitian ini ada 57 orang responden dan mayoritas adalah laki-laki yaitu sebanyak $58 \%$.

\section{Berdasarkan Usia}

Tabel 4.2

Karakteristik Berdasarkan Usia

\begin{tabular}{|c|c|c|}
\hline Usia & Jumlah Responden & Persentase (\%) \\
\hline 30-39 Tahun & 10 & $18 \%$ \\
\hline 40-49 Tahun & 21 & $37 \%$ \\
\hline$>50$ Tahun & 26 & $46 \%$ \\
\hline Total & 57 & $100 \%$ \\
\hline
\end{tabular}

Dari tabel 4.2 diketahui bahwa responden didominasi oleh pegawai dengan usia lebih dari 50 tahun yaitu sebesar $46 \%$.

\section{Berdasarkan Pendidikan Terakhir}

Tabel 4.3

Karakteristik Responden Berdasarkan Pendidikan Terakhir

\begin{tabular}{|c|c|c|}
\hline Pendidikan & Jumlah Responden & Persentase (\%) \\
\hline SMA & 17 & $30 \%$ \\
\hline Diploma & 15 & $26 \%$ \\
\hline S1 & 16 & $28 \%$ \\
\hline S2 & 9 & $16 \%$ \\
\hline Total & 57 & $100 \%$ \\
\hline
\end{tabular}

Dari tabel 4.3 diketahui bahwa responden didominasi oleh pegawai dengan pendidikan terakhir SMA yaitu sebesar $30 \%$. 
Pengaruh Budaya Organisasi dan Etos Kerja terhadap Kinerja Pegawai (Studi Kasus Dinas Kelautan dan Perikanan Daerah Istimewa Yogyakarta)

\section{Uji Instrumen}

\section{Uji Validitas}

Tabel 4.4

Ringkasan Uji Validitas Instrumen Penelitian

\begin{tabular}{|c|c|c|c|c|}
\hline Variabel & Butir & R hitung & $\mathrm{R}$ tabel & Keterangan \\
\hline \multirow{12}{*}{ Etos Kerja } & 1 & 0.545 & 0.260 & Valid \\
\hline & 2 & 0.555 & 0.260 & Valid \\
\hline & 3 & 0.832 & 0.260 & Valid \\
\hline & 4 & 0.690 & 0.260 & Valid \\
\hline & 5 & 0.731 & 0.260 & Valid \\
\hline & 6 & 0.752 & 0.260 & Valid \\
\hline & 7 & 0.686 & 0.260 & Valid \\
\hline & 8 & 0.728 & 0.260 & Valid \\
\hline & 9 & 0.610 & 0.260 & Valid \\
\hline & 10 & 0.634 & 0.260 & Valid \\
\hline & 11 & 0.610 & 0.260 & Valid \\
\hline & 12 & 0.602 & 0.260 & Valid \\
\hline \multirow{14}{*}{ Budaya Organisasi } & 1 & 0.510 & 0.260 & Valid \\
\hline & 2 & 0.511 & 0.260 & Valid \\
\hline & 3 & 0.549 & 0.260 & Valid \\
\hline & 4 & 0.407 & 0.260 & Valid \\
\hline & 5 & 0.520 & 0.260 & Valid \\
\hline & 6 & 0.436 & 0.260 & Valid \\
\hline & 7 & 0.356 & 0.260 & Valid \\
\hline & 8 & 0.613 & 0.260 & Valid \\
\hline & 9 & 0.354 & 0.260 & Valid \\
\hline & 10 & 0.406 & 0.260 & Valid \\
\hline & 11 & 0.546 & 0.260 & Valid \\
\hline & 12 & 0.565 & 0.260 & Valid \\
\hline & 13 & 0.521 & 0.260 & Valid \\
\hline & 14 & 0.550 & 0.260 & Valid \\
\hline \multirow{11}{*}{ Kinerja Karyawan } & 1 & 0.615 & 0.260 & Valid \\
\hline & 2 & 0.327 & 0.260 & Valid \\
\hline & 3 & 0.310 & 0.260 & Valid \\
\hline & 4 & 0.578 & 0.260 & Valid \\
\hline & 5 & 0.412 & 0.260 & Valid \\
\hline & 6 & 0.267 & 0.260 & Valid \\
\hline & 7 & 0.601 & 0.260 & Valid \\
\hline & 8 & 0.531 & 0.260 & Valid \\
\hline & 9 & 0.442 & 0.260 & Valid \\
\hline & 10 & 0.387 & 0.260 & Valid \\
\hline & 11 & 0.544 & 0.260 & Valid \\
\hline
\end{tabular}

Dari tabel 4.4 uji validitas di atas nilai r-hitung setiap indikator variabel lebih besar dibandingkan r-tabel. Artinya nilai correlated item-total correlation dari 37 pertanyaan dinyatakan valid.

\section{Uji Reliabilitas}

Tabel 4.5

Hasil Analisis Reliabillity Instrumen Penelitian Reliabillity Statistic

\begin{tabular}{|l|c|c|c|}
\hline \multicolumn{1}{|c|}{ Variabel } & $\begin{array}{c}\text { Crombach's } \\
\text { Alpha }\end{array}$ & N of Items & Keterangan \\
\hline Etos Kerja (X1) & 0.884 & 12 & Reliabel \\
\hline $\begin{array}{l}\text { Budaya Organisasi } \\
\text { (X2) }\end{array}$ & 0.752 & 14 & Reliabel \\
\hline $\begin{array}{l}\text { Kinerja Karyawan } \\
(Y)\end{array}$ & 0.609 & 11 & Reliabel \\
\hline
\end{tabular}

Berdasarkan hasil pengujian reliabilitas dari tabel 4.5 di atas diketahui bahwa nilai Cronbach's Alpha untuk masing-masing instrumen yang diuji adalah 0,884 untuk variabel etos kerja, 0,752 untuk variabel budaya organisasi, dan 0,609 untuk variabel kinerja. Suatu instrumen dinyatakan reliabel bila koefisien reliabilitas minimal 0,06 (Ghozali, 2012). Jadi dapat disimpulkan bahwa instrumen penelitian yang digunakan untuk mengukur variabel penelitian ini dapat dikatakan reliabel.

\section{Uji Asumsi Klasik}

1. Uji Normalitas

Tabel 4.6

Hasil Uji Normalitas Data

One-Sample Kolmogorov_Smirnov Test

\begin{tabular}{|ll|r|}
\hline & & $\begin{array}{r}\text { Unstandardized } \\
\text { Residual }\end{array}$ \\
\hline $\mathrm{N}$ & Mean & 57 \\
Normal Parameters ${ }^{\mathrm{a}, \mathrm{b}}$ & $\mathrm{0E-7}$ \\
& Std. Deviation & 1.93105174 \\
& Absolute & .115 \\
Most Extreme & Positive & .115 \\
Differences & Negative & -.096 \\
Test Statistic & & .115 \\
Asymp. Sig. (2-tailed) & & $.056^{c}$ \\
\hline
\end{tabular}

a. Test distribution is Normal.

b. Calculated from data

Berdasarkan hasil uji normalitas dari tabel 4.6 di atas diketahui nilai signifikansi 0,056 lebih besar 0,05, maka dapat disimpulkan bahwa nilai residual berdistribusi normal.

\section{Uji Multikolinieritas}

Tabel 4.7

Hasil Uji Multiikolinieritas Coefficients $^{\mathbf{a}}$

\begin{tabular}{|c|c|c|c|c|c|c|c|}
\hline \multirow[t]{2}{*}{$\overline{\text { Model }}$} & \multicolumn{2}{|c|}{$\begin{array}{l}\text { Unstandardized } \\
\text { Coefficients }\end{array}$} & \multirow{2}{*}{\begin{tabular}{|c|}
$\begin{array}{c}\text { Standardized } \\
\text { Coefficients }\end{array}$ \\
Beta \\
\end{tabular}} & \multirow[t]{2}{*}{$\bar{T}$} & \multirow[t]{2}{*}{ Sig. } & \multicolumn{2}{|c|}{$\begin{array}{l}\text { Collinearity } \\
\text { Statistics }\end{array}$} \\
\hline & $B$ & $\begin{array}{l}\text { Std. } \\
\text { Error }\end{array}$ & & & & Tolerance & $V \mid F$ \\
\hline (Constant) & 10.714 & 3.826 & & 2.800 & .007 & & \\
\hline Total_EK & .260 & .084 & .386 & 3.097 & .003 & .648 & 1.542 \\
\hline Total BO & .314 & .105 & .372 & 2.986 & .004 & .648 & 1.542 \\
\hline
\end{tabular}

a. Dependent Variable: Total_K1 
Berdasarkan tabel 4.7 di atas diketahui bahwa hasil perhitungan menunjukan bahwa nilai VIF atau Variance Inflation Factor dari variabel etos kerja dan budaya organisasi sebesar 1,542. Nilai-nilai tersebut semuanya lebih kecil dari 10. Sedangkan nilai tolerance untuk variabel etos kerja dan budaya organisasi sebesar 0,648 lebih besar dari 0,10. Hal ini dapat disimpulkan bahwa dalam model regresi tidak ditemukan adanya korelasi antar variabel bebas (independen).

\section{Uji Heteroskedastisitas}

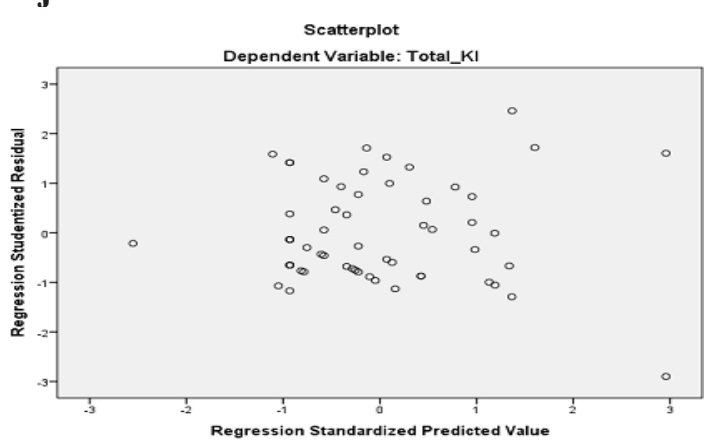

Gambar 4.1

Hasil Uji Heteroskedastisitas

Dari gambar di atas dapat diketahui bahwa tidak terjadi heteroskedastisitas sebab tidak ada pola yang jelas, serta titiktitik menyebar di atas dan di bawah angka 0 pada sumbu $Y$, sehingga dapat dikatakan uji heteroskedastisitas terpenuhi.

\section{Analisis Regresi Linier Berganda}

Tabel 4.8

Uji Regresi Linier Berganda Coefficients $^{\mathrm{a}}$

\begin{tabular}{|c|c|c|c|c|c|}
\hline \multirow[t]{2}{*}{ Model } & \multicolumn{2}{|c|}{$\begin{array}{l}\text { Unstandardized } \\
\text { Coefficients }\end{array}$} & $\begin{array}{l}\text { Standardized } \\
\text { Coefficients }\end{array}$ & \multirow[t]{2}{*}{$\mathrm{T}$} & \multirow[t]{2}{*}{ Sig. } \\
\hline & $B$ & Std. Error & Beta & & \\
\hline (Constant) & 10.714 & 3.826 & & 2.800 & .007 \\
\hline 1 Total_EK & .260 & .084 & .386 & 3.097 & .003 \\
\hline Total_BO & .314 & . 105 & .372 & 2.986 & .004 \\
\hline
\end{tabular}

a. Dependent Variable: Total_Kl
Dari data tabel 4.8 di atas dapat diperoleh persamaan regresi linear berganda sebagai berikut:

$\mathrm{Y}=10,714+0,386 \mathrm{X}_{1}+0,372 \mathrm{X}_{2}$

1) Konstanta $=10,714$

Dari hasil persamaan uji regresi linear berganda, diperoleh nilai konstanta adalah positif sebesar 10,714. Artinya walaupun tidak ada variabel etos kerja $\left(X_{1}\right)$ dan budaya organisasi $\left(X_{2}\right)$ yang mempengaruhi kinerja karyawan, maka nilai kinerja karyawan tersebut sebesar 10,714 .

2) Koefisien Regresi $\beta_{1}=0,386$

Nilai koefisien regresi $\beta_{1}$ positif sebesar 0,386. Artinya, jika variabel etos kerja meningkat sebesar satu satuan, maka kinerja karyawan akan meningkat sebesar 0,386 dengan anggapan variabel bebas lainnya tetap.

3) Koefisien Regresi $\beta_{2}=0,372$

Nilai koefisien regresi $\beta_{2}$ positif sebesar 0,372. Artinya, jika variabel budaya organisasi meningkat sebesar satu satuan, maka kinerja karyawan akan meningkat sebesar 0,372 dengan anggapan variabel bebas lainnya tetap.

\section{Uji Hipotesis}

\section{Uji Parsial (Uji T)}

\section{Tabel 4.9}

Hasil Uji t

Coefficients $^{\mathrm{a}}$

\begin{tabular}{|c|c|c|c|c|c|}
\hline \multirow[t]{2}{*}{ Model } & \multicolumn{2}{|c|}{$\begin{array}{c}\text { Unstandardized } \\
\text { Coefficients }\end{array}$} & \multirow{2}{*}{$\begin{array}{c}\begin{array}{c}\text { Standardized } \\
\text { Coefficients }\end{array} \\
\text { Beta } \\
\end{array}$} & \multirow[t]{2}{*}{1} & \multirow[t]{2}{*}{ Sig. } \\
\hline & $B$ & Std. Error & & & \\
\hline (Constant) & 10.714 & 3.826 & & 2.800 & .007 \\
\hline 1 Total_EK & .260 & .084 & .386 & 3.097 & .003 \\
\hline Total BO & .314 & .105 & .372 & 2.986 & .004 \\
\hline
\end{tabular}

a. Dependent Variable: Total_K1

Uji parsial $t$ dilakukan dengan melihat nilai signifikansi $<0,05$ untuk mengetahui pengaruh secara parsial antara variabel independen dengan variabel dependen.

1) Pengaruh Etos Kerja terhadap Kinerja Pegawai

Berdasarkan tabel analisis regresi diperoleh koefisien 0,260 
Pengaruh Budaya Organisasi dan Etos Kerja terhadap Kinerja Pegawai (Studi Kasus Dinas Kelautan dan Perikanan

Daerah Istimewa Yogyakarta)

dan nilai signifikansi $0,003<0,05$, maka dapat disimpulkan bahwa etos kerja $\left(X_{1}\right)$ berpengaruh positif dan signifikan terhadap kinerja pegawai (Y).

2) Pengaruh Budaya Organisasi terhadap Kinerja Pegawai

Hasil analisis regresi diperoleh nilai koefisien 0,314 dan nilai signifikansi 0,004 $<0,05$, maka dapat disimpulkan budaya organisasi $\left(\mathrm{X}_{2}\right)$ berpengaruh signifikan terhadap kinerja pegawai $(\mathrm{Y})$.

\section{Uji Simultan (Uji F)}

\section{Tabel 4.10}

\section{Hasil Uji F}

\begin{tabular}{|c|c|c|c|c|c|c|}
\hline \multicolumn{2}{|c|}{ Model } & $\begin{array}{l}\text { Sum of } \\
\text { Squares }\end{array}$ & Df & $\begin{array}{l}\text { Mean } \\
\text { Square }\end{array}$ & $F$ & \begin{tabular}{|l|} 
Sig. \\
\end{tabular} \\
\hline \multirow{3}{*}{1} & Regression & 175.740 & 2 & 87.870 & 22.723 & \\
\hline & Residual & 208.822 & 54 & 3.867 & & \\
\hline & Total & 384.561 & 56 & & & \\
\hline
\end{tabular}

a. Dependent Variable: Tota__KI

\section{b. Predictors: (Constant), Total_BO, Tota__EK}

a. Dependent Variable: Total_K1

b. Predictors: (Constant), Total_BO, Total_EK

Berdasarkan hasil dari tabel 4.10 uji $\mathrm{F}$, diperoleh nilai signifikansi sebesar $0,000<0,05$. Maka dapat disimpulkan bahwa bahwa etos kerja $\left(\mathrm{X}_{1}\right)$ dan budaya organisasi $\left(\mathrm{X}_{2}\right)$ berpengaruh secara simultan berpengaruh signifikan terhadap kinerja pegawai.

\section{Uji Koefisien Determinasi}

Tabel 4.11

Hasil Uji Koefisien Determinasi Model Summary

\begin{tabular}{|l|r|r|r|r|}
\hline Model & \multicolumn{1}{|c|}{$R$} & R Square & $\begin{array}{c}\text { Adjusted } R \\
\text { Square }\end{array}$ & $\begin{array}{r}\text { Std. Error of } \\
\text { the Estimate }\end{array}$ \\
\hline 1 & $.676^{2}$ & .457 & .437 & 1.9665 \\
\hline
\end{tabular}

a. Predictors: (Constant), Total_BO, Total_BE

Tabel $4.11 \mathrm{di}$ atas menunjukkan bahwa nilai adjusted $R$ square sebesar 0,437 . Hal ini berarti $43,7 \%$ dari variabel kinerja pegawai dapat dijelaskan oleh variabel etos kerja dan budaya organisasi, sedangkan sisanya $56,3 \%$ dijelaskan oleh variabel lain yang tidak diteliti pada penelitian ini.

\section{Pembahasan}

\section{Pengaruh Positif Etos Kerja terhadap Kinerja Karyawan}

Berdasarkan hasil analisis pada uji t, variabel etos kerja menunjukkan nilai koefisien 0,260 dan tingkat signifikansi sebesar 0,003 lebih kecil dari 0,05, maka dapat disimpulkan terdapat pengaruh positif etos kerja $\left(\mathrm{X}_{1}\right)$ terhadap kinerja pegawai (Y). Hipotesis pertama yang mengatakan etos kerja berpengaruh positif terhadap kinerja karyawan diterima.

Sebagaimana telah disebutkan pada bab sebelumnya bahwa etos kerja merupakan keadaan dimana para pegawai harus memiliki sikap, perilaku positif, kepribadian, dan keyakinan atas sesuatu, dengan adanya perilaku yang positif, maka para pegawai akan bekerja lebih produktif dan dapat bekerja dengan hasil yang maksimal. Etos kerja kerja terjadi kepada pegawai yang kurang disiplin, kurang bertanggung jawab atas pekerjaannya dan memiliki sikap yang kurang baik terhadap sesama pegawai. Hal tersebut akan mengakibatkan menurunnya kinerja seorang pegawai dan berakibat buruk kepada suatu organisasi.

\section{Pengaruh Positif Budaya Organisasi terhadap Kinerja Karyawan}

Berdasarkan hasil analisis pada uji t, variabel budaya organisasi menunjukkan nilai koefisien 0,314 dengan tingkat signifikansi sebesar 0,004 lebih kecil dari 0,05, maka dapat disimpulkan terdapat pengaruh positif budaya organisasi $\left(\mathrm{X}_{2}\right)$ terhadap kinerja pegawai (Y). Hipotesis kedua yang mengatakan terdapat pengaruh positif budaya organisasi terhadap kinerja karyawan diterima.

Budaya organisasi memiliki peran penting untuk mendorong dan 
meningkatkan kinerja pegawai, serta sebagai alat untuk menentukan arah organisasi, mengarahkan apa yang boleh dan apa yang tidak boleh. Dengan membangun komitmen bersama dan membimbing, serta membentuk sikap dan perilaku pegawai, maka budaya organisasi yang terdapat di organisasi tersebut akan berjalan lebih baik

\section{EtosKerjadan Budaya Organisasisecara Simultan Berpengaruh Signifikan terhadap Kinerja Karyawan}

Berdasarkan dari hasil uji $F$ menunjukkan nilai signifikansi sebesar $0,000<0,05$. Hal ini mengindikasikan bahwa secara simultan kinerja pegawai dipengaruhi oleh etos kerja dan budaya organisasi.

\section{KESIMPULAN DAN SARAN}

\section{Kesimpulan}

Berdasarkan hasil penelitian di atas, maka dapat disimpulkan bahwa:

1. Terdapat pengaruh positif etos kerja terhadap kinerja pegawai Dinas Kelautan dan Perikanan DIY. Hal ini dibuktikan dengan nilai koefisien 0,260 dan nilai signifikansi sebesar 0,003 lebih kecil dari 0,05 . Artinya, hipotesis pertama yang mengatakan terdapat pengaruh positif etos kerja terhadap kinerja pegawai diterima.

2. Terdapat pengaruh positif budaya organisasi terhadap kinerja pegawai Dinas Kelautan dan Perikanan DIY. Hal ini dibuktikan berdasarkan hasil uji statistik t variabel budaya organisasi $\left(\mathrm{X}_{2}\right)$ mempunyai nilai koefisien 0,314 dan nilai signifikansi sebesar 0,004 lebih kecil dari 0,05. Artinya, hipotesis kedua yang mengatakan terdapat pengaruh positif budaya organisasi terhadap kinerja pegawai diterima.

3. Terdapat pengaruh etos kerja dan budaya organisasi secara simultan terhadap kinerja pegawai Dinas Kelautan dan Perikanan DIY. Hal ini dibuktikan berdasarkan nilai signifikansi sebesar 0,000 lebih kecil dari 0,0 . Artinya, hipotesis ketiga yang mengatakan terdapat pengaruh simultan etos kerja dan budaya organisasi terhadap kinerja pegawai diterima.

\section{Saran}

Saran yang dapat diberikan dalam penelitian ini di antaranya:

1. Berdasarkan hasil penelitian diketahui bahwa pada variabel etos kerja yang terletak pada indikator terendah yaitu rajin dengan nilai sebesar 3,16, maka penulis memberikan saran kepada pimpinan organisasi untuk menindaklanjuti permasalahan yang terkait dengan kondisi pekerjaan, hendaknya pegawai meningkatkan dan menanamkan etos kerja dalam wujud meningkatnya sikap rajin dalam hal lebih efektif bekerja sejak dini, misalnya bersungguh-sungguh dalam melaksanakan kewajiban untuk bekerja. Pimpinan seharusnya memberikan reward kepada pegawai yang rajin dan memberikan sanksi kepada pegawai yang bermalas-malasan dalam bekerja. Langkah-langkah ini diharapkan dapat meningkatkan etos kerja dan kinerja pegawai Dinas Kelautan dan Perikanan DIY.

2. Berdasarkan hasil penelitian diketahui bahwa pada variabel budaya organisasi yang terletak pada indikator terendah, yaitu perhatian terhadap hal yang detail dengan nilai sebesar 3,02. Keberhasilan kinerja organisasi salah satunya ditentukan dari sejauh mana seorang pegawai dapat memperhatikan kecermatan, dalam analisis masalah yang sedang dihadapi dan perhatian terhadap hal-hal kecil yang dapat menjadi faktor penghambat jalannya kegiatan organisasi, maka seharusnya pegawai lebih benyak belajar dengan demikian pegawai akan lebih peka dalam kemampuan menganalisis. Pegawai membuat rencana kerja secara 
Pengaruh Budaya Organisasi dan Etos Kerja terhadap Kinerja Pegawai (Studi Kasus Dinas Kelautan dan Perikanan

Daerah Istimewa Yogyakarta)

lengkap dan rinci hal ini bertujuan untuk menjadi panduan atau acuan jika tiba-tiba ada masalah ataupun sesuatu yang tidak diinginkan.

3. Berdasarkan hasil penelitian diketahui bahwa pada variabel kinerja yang terletak pada indikator terendah adalah kuantitas pekerjaan dengan nilai sebesar 3,42. Untuk meningkatkan kuantitas pegawai dapat ditempuh dengan perekrutan pegawai yang berkompetensi, maka pegawai akan lebih kompeten pada pekerjaannya. Selain itu, pimpinan juga memberikan pelatihan kerja, pembinaan untuk para pegawai agar lebih berkualitas dalam bekerja.

\section{DAFTAR PUSTAKA}

Ardana, I Komang., Ni Wayan Mujiati., dan I Wayan Mudiartha Utama. (2012). Manajemen Sumber Daya Manusia. Edisi Pertama. Yogyakarta: Graha Ilmu.

Arikunto, Suharsimi. (2010). Prosedur Penelitian Suatu Pendekatan Praktek. Jakarta: Rineka Cipta.

Ghozali, Imam. (2012). Aplikasi Analisis Multivariate dengan Program IBMSPSS 20. Edisi Keenam. Semarang: Badan Penerbit Universitas Diponegoro.

Ghozali, Imam. (2018). Aplikasi Analisis Multivariate dengan Program IBM SPSS 25. Edisi 9. Semarang: Badan Penerbit Universitas Diponegoro.

Hasibuan, Malayu. (2013). Manajemen Sumber Daya Manusia. Jakarta: PT Bumi Aksara.

Intan. (2017). Pengaruh Budaya Organisasi, Komitmen Organisasi, Kompensasi, dan Etos Kerja terhadap Kinerja
Pegawai Kementerian Ketenagakerjaan Republik Indonesia. Jurnal Ilmu Manajemen. Vol. 3, No. 2. 2017.

Karauwan, Raynald. (2015). Pengaruh Etos Kerja Budaya Organisasi dan Beban Kerja terhadap Kinerja Pegawai di Dinas Pekerjaan Umum Minahasa Selatan. Jurnal Emba. Vol.3, No. 3. 2015.

Mangkunegara, Anwar Prabu. (2013). Manajemen Sumber Daya Manusia Perusahaan. Bandung: PT Remaja Rosda Karya.

Mangkunegara, Anwar Prabu. (2017). Manajemen Sumber Daya Manusia Perusahaan. Bandung: PT Remaja Rosda Karya.

Moeheriono. (2012). Pengukuran Kinerja Berbasis Kompetensi. Edisi Revisi. Jakarta: PT. Rineka Cipta.

Nawawi, Ismail. (2013). Budaya Organisasi Kepemimpinan dan Kinerja. Cetakan Pertama. Jakarta: Kencana Prenada Media.

Pramana, Ridwan Mahgribbi. (2017). Pengaruh Etos Kerja Islami, Good Corporate Governance, dan Gaya Kepemimpinan Transformasional terhadap Kinerja Karyawan Bagian Akuntansi. Skripsi. Universitas Muhammadiyah Yogyakarta.

Riani, Asri Laksimi. (2011). Budaya Organisasi. Yogyakarta: Graha Ilmu.

Sinamon, Jansen, H. (2011). Etos Kerja Profesional Navigator Anda Menuju Sukses. Jakarta: PT. Spirit Mahardika.

Sugiyono. (2013). Metode Penelitian Pendidikan Pendekatan Kuantitatif, Kualitatif, dan $R \& D$. Bandung: Alfabeta. 
Sugiyono. (2014). Cara Mudah Menyusun Skripsi, Tesis, dan Desertasi. Cetakan Kedua. Bandung: Alfabeta.

Sugiyono.(2015). MetodePenelitian Pendidikan Pendekatan Kuantitatif, Kualitatif, dan $R \& D$. Bandung: Alfabeta.

Wibowo. (2013). Budaya Organisasi; Sebuah Kebutuhan untuk Meningkatkan Kinerja Jangka Panjang. Jakarta: PT. Raja Grafindo Persada. 
NOFIKA AMALIA, PUJI ASTUTI

Pengaruh Budaya Organisasi dan Etos Kerja terhadap Kinerja Pegawai (Studi Kasus Dinas Kelautan dan Perikanan Daerah Istimewa Yogyakarta) 